\title{
THE SAPPES GOLD PROJECT
}

\section{A. J. SHAWH ${ }^{1} \&$ D.C. CONSTANTINIDES ${ }^{2}$}

\section{EYNO४H}

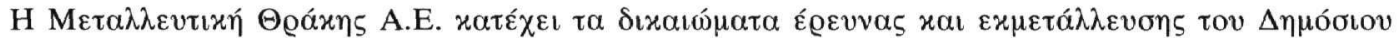

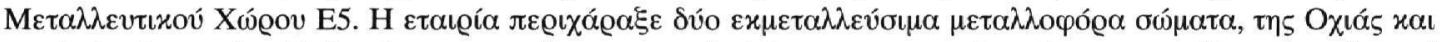

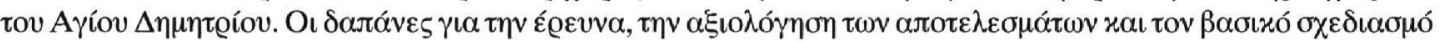

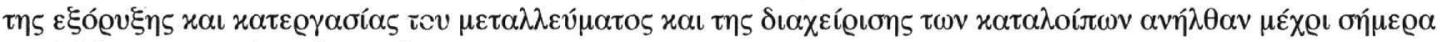

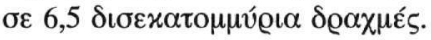

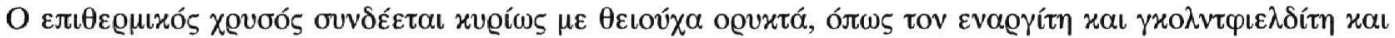

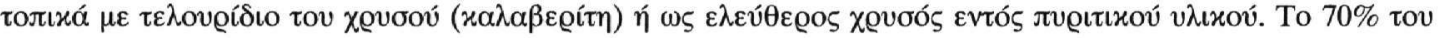

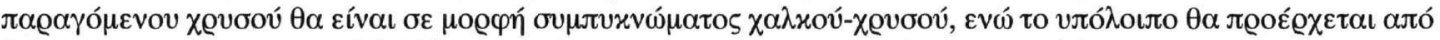

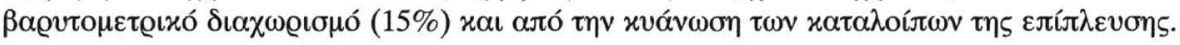

KEY WORDS: Sappes, E5 Mining Lease Area, Rhodope Volcanic Arc, Epithermal Mineralisation, Viper Deposit, St. Demetrios Deposit, Environmental Protection, Mining Methods, Metallurgical Processing, Financial Investments.

\section{REGIONAL SETTING}

The regional setting of the Sappes Gold Project area in north-eastern Greece and the major tectonic and geological features are shown in Figure 1.

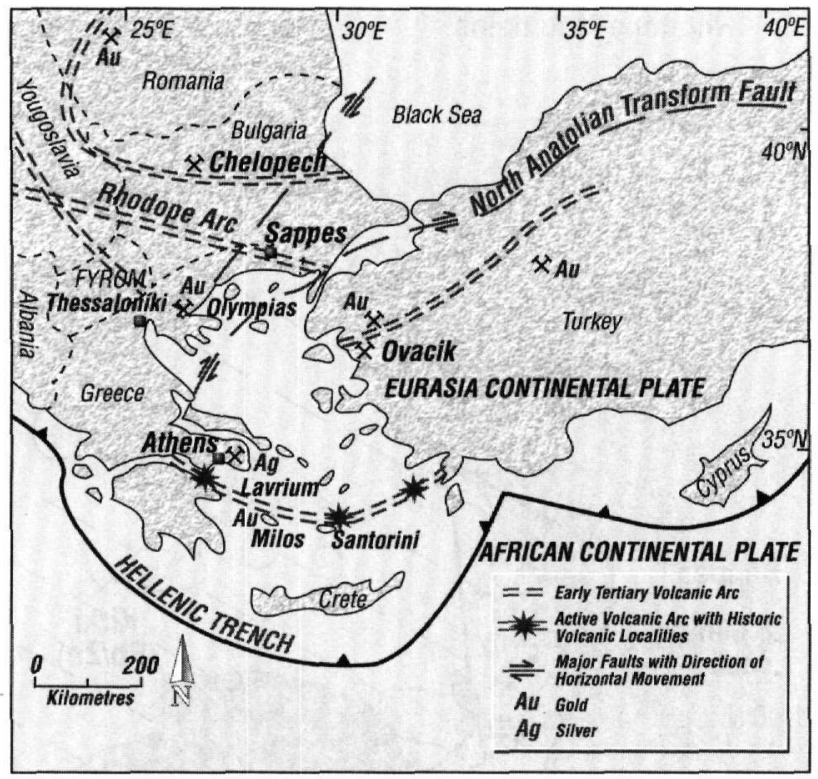

Figure 1. Location of the Sappes Gold Project

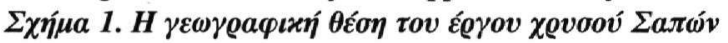

1. Exploration Manager, Greenwich Resources plc, 1 Mathon Place, Mathon, Malvern, Worcestershire WR13 5NZ, England

2. General Manager, Thrace Minerals S.A., Papadima 74, 69300 Sappes, Greece 
The Sappes district is located on the Rhodope Volcanic Arc, one of several subduction-related structures that developed in late-Mesozoic and early-Tertiary times in the Tethys Ocean separating the continental landmasses of Africa and Eurasia (Dewey and Senger, 1979).

The Basement in the region comprises metamorphic rocks of the Upper Palaeozoic Rhodope Massif and the Mesozoic Circum-Rhodope Belt. During the Oligocene, the overlying volcanic sequences developed and the mineralising events occurred together with the formation of structurally controlled basins (Innocenti et al, 1984). A widespread series of Neogene and Quaternary sediments overlie the earlier formations.

\section{SAPPES DISTRICT GEOLOGY}

The Project Area is located in the E5 Mining Lease Area, granted in 1993 by the Ministry of Development following an International Tender.

The Sappes district lies on the eastern margin of the Komotini Graben or Basin, the geology of which is shown in Figure 2. Basement Makri schists crop out in the southern part of the Lease Area, locally overlain by Eocene basal conglomerate. Most of the area is underlain by Tertiary volcanic and pyroclastic rocks, which are very variable in nature reflecting the facies variations within an andesitic strato-volcanic succession. The occurrence of sub-volcanic rhyodacite outcrops and the monzodiorite intrusive indicates that the original volcanic centre lies to the east and northeast of the Lease. The Silver Hills Conglomerate covers a significant part of the northern area of the Lease, the poorly sorted nature and composition of which suggest that it is a mass flow deposited marginal to the Komotini Graben during its subsidence. Quaternary alluvium covers the western edge of the Lease and obscures the graben-margin faults.

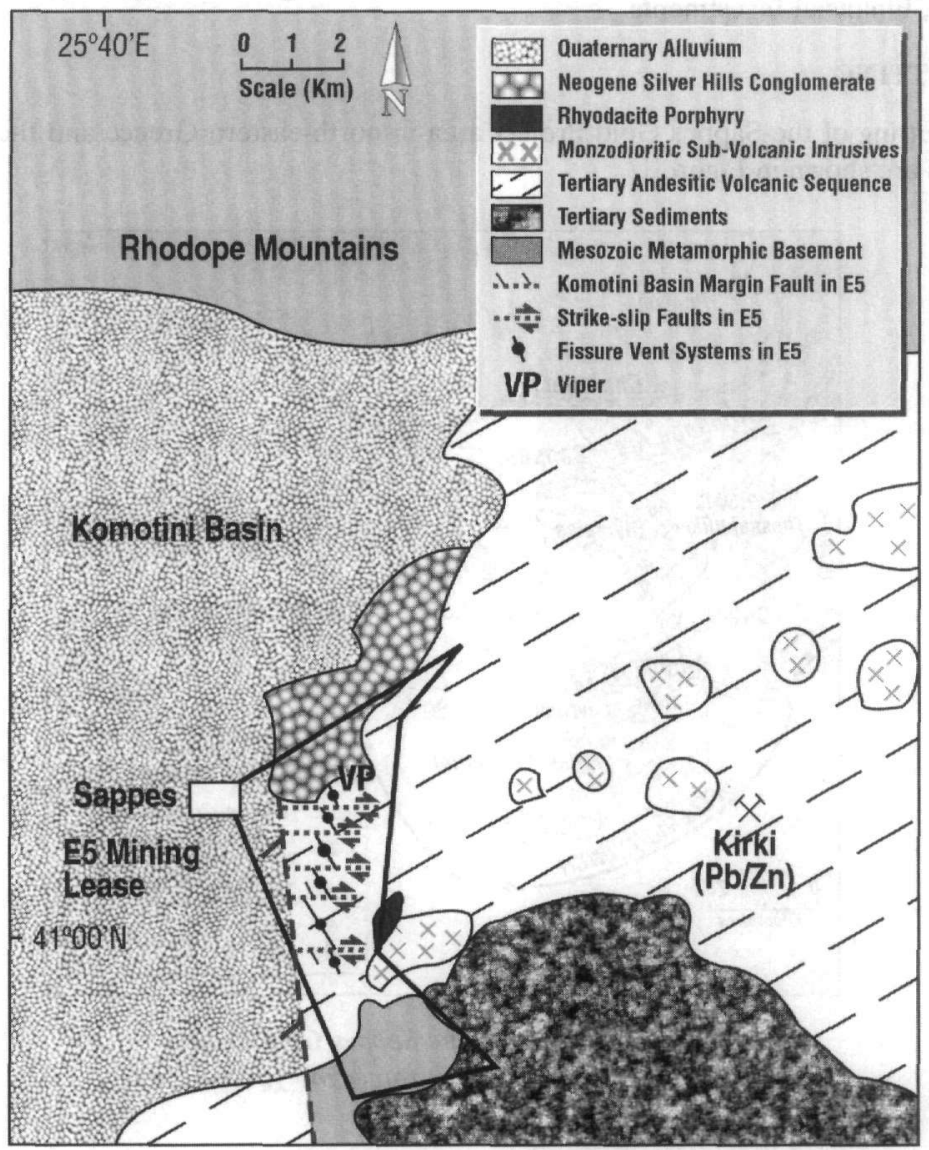

Figure 2. Geology of the Sappes District

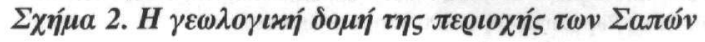


A large proportion of the volcanic sequence has been affected by intense hydrothermal alteration. Argillicsericitic alteration is the most extensive. Zones of siliceous alteration are mainly confined to distinct structural trends and alunite alteration tends to occur both peripherally and below zones of silicification. Propylitic alteration is mostly confined to the northern part of the Lease with relic lenses locally within areas of argillisation.

The structural history is complex, ovoid lineaments appear to reflect doming during the emplacement of rhyodacite porphyry bodies. A strong north-westerly lineation marked by a series of silica outcrops can be traced over some $6 \mathrm{~km}$ within the Lease. They are considered to mark the location of a fissure vent system that was one of the main sources and pathway of the mineralising fluids. Younger easterly trending right lateral strike-slip faults, consistent with the movement on the major North Anatolian Transform Fault, displace the vent system outcrops and north-easterly normal faults have caused vertical displacements of the mineralisation.

\section{EXPLORATION TO DATE}

The Institute of Geology and Mineralogy (IGME) initiated systematic exploration of the area in 1987. The work included geophysical and geochemical surveys and a total of $1835 \mathrm{~m}$ of drilling. These activities led to the identification of the first epithermal gold prospect in Greece, at St. Demetrios, and recognised the petrology and mineralogy of the hydrothermal alteration styles in the region (Michael, 1993).

Epithermal gold and silver mineralisation was also identified near Kassiteres in the southern part of the E5 Lease Area during PhD research studies (Voudouris, 1993). Exploration in Thrace Region led to the early discovery of epithermal high sulphidation base metal mineralisation near Kirki, where the Agios Filippos Vein was mined at various times during the last century (Skarpelis, 1999).

The Company began exploration in 1993; the results of the earlier phases of the work were published by Bridges et al. (1997). To-date, the Company has completed detailed geological mapping, stream sediment and soil geochemical surveys, rock-chip sampling of outcrops, trenching, ground and airborne geophysical surveys, over $36,000 \mathrm{~m}$ of drilling, the development of water wells, environmental, geotechnical and techno-economic studies, orebody modelling and reserve calculations, and mine planning and design.

The exploration discovered other prospects that host epithermal gold mineralisation in addition to that at St. Demetrios. Detailed evaluations were completed over the Viper, St. Demetrios and Scarp prospects.

\section{THE VIPER DEPOSIT}

The Viper deposit occurs in the north-western sector of the Lease, south of the westerly draining Viper Creek that marks the southern limit of the Silver Hills Conglomerate. North-westerly trending silica outcrops, originally thought to be sinters, extend across the area and formed the original target for exploration and drilling.

These rocks mark a steeply dipping fissure vent system that was active until late in the history of the Sappes volcanic centre. The vent zone, plus the surrounding alteration halo, is up to $150 \mathrm{~m}$ wide and near surface comprises an anastamosing system of amorphous silica veins with minor baryte within the volcanic sequence that has been argillised and brecciated as a result of the activity. Quartz-chalcedony veins occur at greater depths, as does silica-alunite mineralisation. The host volcanic rocks have been strongly brecciated and for the most part are strongly silicified.

The outcrops have a low gold content of up to $1.7 \mathrm{~g} / \mathrm{t}$ Au but are high in silver up to almost $300 \mathrm{~g} / \mathrm{t}$. However, the drill intersections show that the geochemistry changes with depth from a silver-dominated system to a golddominated system at a depth of about $+100 \mathrm{~m} \mathrm{RL}$. This may indicate a mixing or boiling level that led to the deposition of gold.

The stratigraphy of the volcanic succession, as revealed by drilling east of the vent, is shown in the schematic long-section through Viper, Figure 3. A pyroclastic unit, mainly lithic tuff occurs at surface and has a basal contact that dips at about 20 I to the southwest, increasing in thickness from about $10 \mathrm{~m}$ to $50 \mathrm{~m}$ westwards across Viper. Beneath lie two distinct andesitic lava flows separated by a layer of crystal and ash tuff, which locally 
contains fragments of carbonised plant material. The upper flow is composed of hornblende-feldspar porphyry, is generally fresh and magnetic with argillised fracture zones locally. The lower flow is composed of biotitefeldspar porphyry with a chlorite-illite-carbonate alteration overprint of variable intensity.

Most of the Viper mineralisation occurs between the two lava flows hosted by crumble breccias forming the margins to the flows and the tuff horizon between them. Such lithologies constitute a more permeable zone and have acted as the initial lateral pathway for mineralising magmatic fluids originating from the fissure vent system. This led to the development of a silicified horizon between the two flows, which lies about $250 \mathrm{~m}$ below surface, has a gentle southerly dip, is up to $60 \mathrm{~m}$ thick in the western part adjacent to the vent system thinning to $3 \mathrm{~m}$ at the eastern end. Subsequent tectonic and magmatic events have caused brittle fracturing within this horizon and resulted in the deposition of mineralised veins that heal the fractures. The multiphase events are characterised by changes in the chemical composition of the magmatic fluids between subsequent events.

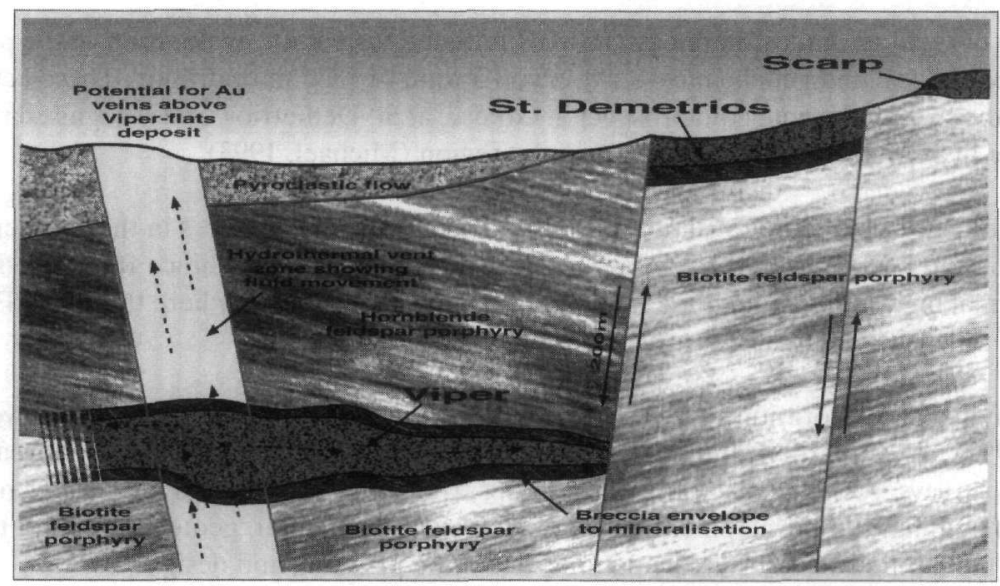

Figure 3. Schematic long-section through the Viper, St. Demetrios and Scarp deposits

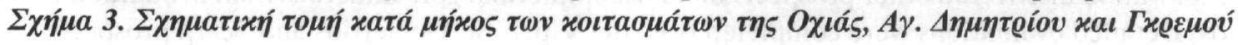

The earliest form of mineralisation comprises dark grey high-sulphidation flood silicification with later phases depositing medium to pale grey silica, silica-alunite, quartz-chalcedony, opaline, amethystine and comb quartz as brittle fracture healing with a late-stage phase filled with kaolinite/dickite. Gold is most commonly associated with sulphide minerals such as enargite and goldfieldite, and locally as gold telluride (calaverite) and as coarsegrains of free gold within silica. Other minerals occurring within the horizon include pyrite, galena, sphalerite, chalcopyrite, intergrown chalcocite and covellite, and bismuthinite.

The easterly limit of the Viper deposit is marked by a south-westerly trending normal fault with a dip and downthrow of $250 \mathrm{~m}$ to the west. The western limit of the deposit has yet to be identified but it may be truncated by another normal fault marginal to the Komotini Graben. The northern and southern limits are not distinct as the silicified horizon is more extensive than the boundary of the gold resource. Gold grades are dependant on the intensity of later mineralising phases, these are not as extensive as the early flood silicification event but they did carry most of the metals.

\section{THE ST. DEMETRIOS DEPOSIT}

The location of the St. Demetrios Deposit east of the normal fault that terminates the Viper deposit is also shown in Figure 3. The mineralisation crops out at surface, is of a high-sulphidation epithermal style and directly overlies a biotite-feldspar porphyry lava flow. Because of their composition, texture and stratigraphic setting it is suggested that St. Demetrios and Viper, as well as Scarp, all formed part of the same deposit having been separated subsequently as a result of late-stage faulting associated with the Komotini Graben.

The St. Demetrios mineralisation has been extensively oxidised and leached. It comprises ferruginous vuggy brecciated silica with later stage quartz, baryte and kaolinite veining, and minor diaspore. It is about $100 \mathrm{~m}$ 
across and extends eastwards from the fault for some $300 \mathrm{~m}$ up to another north-easterly trending fault that separates it from Scarp. The deposit is up to $45 \mathrm{~m}$ thick, almost flat-lying with a gentle southerly dip. Because of the oxidation, the gold occurs as free gold grains within the silica and associated with iron oxides.

\section{THE SCARP DEPOSIT}

The Scarp Deposit lying some $250 \mathrm{~m}$ southeast of St. Demetrios is also shown on Figure 3. The fault separating the two deposits exhibits dextral strike-slip movement of about $250 \mathrm{~m}$ as well as a $40 \mathrm{~m}$ downthrow to the west. Although the two deposits are similar in appearance the gold grades are somewhat lower at Scarp. To date, the gold mineralisation has been proved by drilling to extend eastwards over a length of some $200 \mathrm{~m}$, although the easterly limit has not yet been defined and it is about $150 \mathrm{~m}$ across and generally $40 \mathrm{~m}$ thick. The deposit overlies argillised biotite-feldspar porphyry flow with similar texture and composition to that beneath St. Demetrios and Viper.

\section{OTHER PROSPECTS IDENTIFIED}

Other prospects have been identified in the E5 Mining Lease Area by the Company but have yet to be thoroughly evaluated.

\section{ORE RESERVE AND RESOURCE CALCULATIONS}

Detailed exploration at Viper, St. Demetrios and Scarp enabled the estimation of mineral resources and calculation of reserves for these deposits. These utilised analytical data for representative samples collected from the closely spaced boreholes illustrated in Figure 4, which also gives a 3-dimensional view of the orebodies.

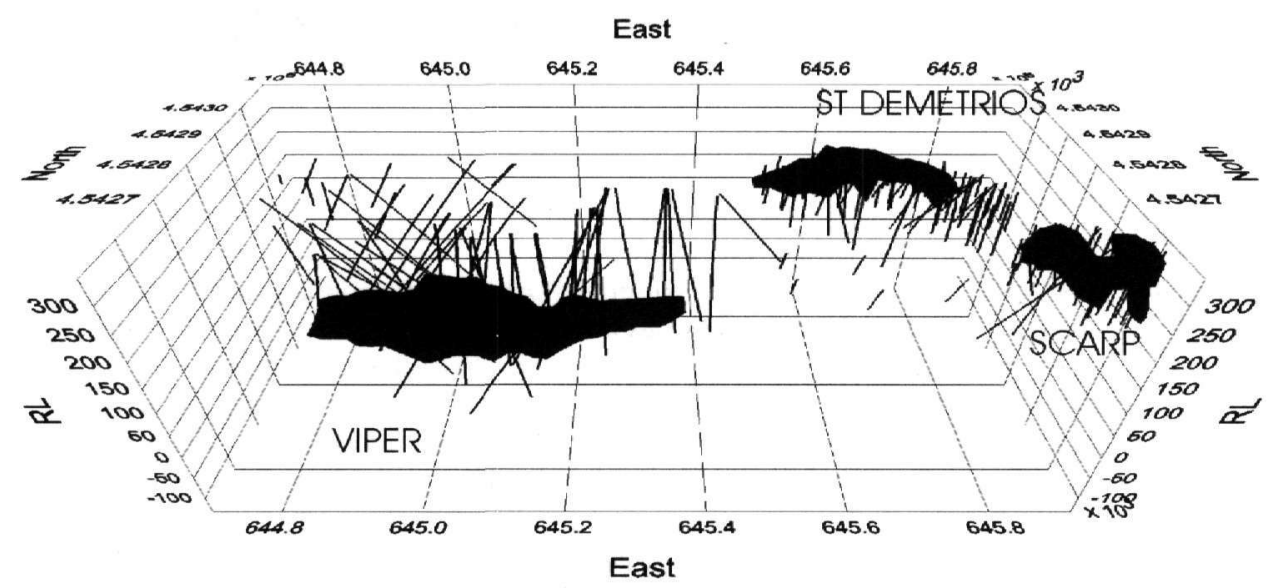

Figure 4. Three-dimensional view of Viper, St. Demetrios and Scarp deposits showing the drill holes

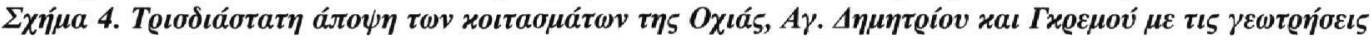

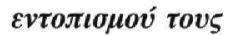

\section{THE VIPER RESERVES}

The Viper orebody is ribbon-like in shape extending some $550 \mathrm{~m}$, in an east-west direction. It is truncated by faulting at the eastern end where it is some $60 \mathrm{~m}$ wide but open towards the west where it is $130 \mathrm{~m}$ wide. The reserve calculation was based on a 3-dimensional wireframe model derived from assay and geological data from diamond drill cores using a $4 \mathrm{~g} / \mathrm{t}$ Au cut-off.

Reserves have been calculated for gold, copper and silver. Copper grades are higher in the eastern part of the orebody than in the west. Gold grades range up to $649 \mathrm{~g} / \mathrm{t}$ Au but an upper cut of $130 \mathrm{~g} / \mathrm{t}$ Au was selected for the purpose of the calculation. Specific Gravity measurements were taken on pieces of core at $5 \mathrm{~m}$ intervals down the length of each hole. The average value determined for the zone of mineralisation was $2.5 \mathrm{t} / \mathrm{m}^{3}$.

The block model for the deposit used $5 \times 5 \times 2 \mathrm{~m}$ (vertical) blocks over the entire orebody and block grades 
were determined by the inverse distance squared weighting method. The rounded reserve figures are given in the table below.

\begin{tabular}{lllcl} 
Viper Tonnes & Gold $(\mathbf{g} / \mathbf{t})$ & \multicolumn{2}{l}{ Silver $(\mathbf{g} / \mathbf{t})$} & Copper $(\%)$ \\
Proven Reserves & 790,000 & 20.1 & 10.6 & 0.37 \\
Probable Reserves & 380,000 & 14.9 & 7.0 & 0.27 \\
Total Reserves & 1.2 million & 18.4 & 9.4 & 0.34
\end{tabular}

\section{THE ST. DEMETRIOS AND SCARP DEPOSITS}

Both deposits are considered to be oxidised low-grade remnants of a silicified gold orebody that also forms Viper. Most of the drilling on these near-surface deposits was by reverse circulation percussion method, with holes generally on a $25 \mathrm{~m}$ grid spacing. As with Viper, wireframe shapes were prepared of the deposits, but using a cut-off grade of $1 \mathrm{~g} / \mathrm{t} \mathrm{Au}$. Calculations were made in a similar way but using a Specific Gravity of $2.27 \mathrm{t} / \mathrm{m}^{3}$, which was derived from tests on core from twinned holes at St. Demetrios.

At its western edge the St. Demetrios Deposit crops out at surface but towards the east it is covered by overburden composed of argillised volcanics, and tends to be thinner and have a lower grade. The average gold grade of the Scarp Deposit at $1.7 \mathrm{~g} / \mathrm{t} \mathrm{Au}$ is also low, consequently reserve calculations have only been prepared for the St. Demetrios West mineralisation that could be easily exploited by open-pit methods. The reserve figures for St. Demetrios West are given in the table below.

\begin{tabular}{|l||c|c|c|c|}
\hline Viper & Tonnes & Gold (g/t) & Silver (g/t) & Copper ( $\mathbf{( q )}$ \\
\hline Proven Reserves & 790,000 & 20.1 & 10.6 & 0.37 \\
\hline Probable Reserves & 380,000 & 14.9 & 7.0 & 0.27 \\
\hline Total Reserves & 1.2 million & 18.4 & 9.4 & 0.34 \\
\hline
\end{tabular}

\section{THE VIPER MINE}

It is planned to mine the 1.2 million tonne Viper Reserve by open-stoping underground methods, utilising a bottom-up strategy with cemented backfill. The workings will progress from west to east along the length of the deposit. This design is to maximise ore recovery, minimise dilution from the hanging wall, and allow access to any higher-level veining and mineralisation. Mine access will be by decline with the ore being hauled by lowprofile dump trucks from the workings to the treatment plant. Ground support for the decline and stopes will include the use of cable bolts, mesh and reinforced fibre shotcrete. The proposed mining method and the use of

\begin{tabular}{|l||l|c|c|c|}
\hline St. Demetrios West & Tonnes & Gold (g/t) & Silver (g/t) & Copper ( 8 ) \\
\hline \hline Proven Reserves & 239,000 & 3.5 & 5.2 & 0.004 \\
\hline Probable Reserves & 25,000 & 3.6 & 4.4 & 0.004 \\
\hline Total Reserves & 264,000 & 3.5 & 5.1 & 0.004 \\
\hline
\end{tabular}

cemented backfill means that there cannot be any surface subsidence as a result of the underground workings.

\section{THE ST. DEMETRIOS PIT}

The St. Demetrios West Reserve will be exploited by a small shallow open-pit where there will be a strip ratio of $0.1: 1$. The ore will be hauled from the pit to the nearby treatment plant, where it will be blended with the ore from Viper.

\section{METALLURGICAL PROCESSING OF THE ORES}

The treatment plant was designed around the mineralogical and metallurgical characteristics of the ores. As Viper ore contains variable amounts of copper in sulphide minerals that are intimately associated with the gold, the standard cyanidation technique would require the use of unacceptably high quantities of cyanide. Consequently, considerable effort has been made to design a plant to enable maximum recoveries using a minimum amount of cyanide. 
The plant will process some 290,000 tonnes of ore per year with $250,000 \mathrm{t}$ coming from Viper and the remaining 40,000 t from the St. Demetrios pit. Because of the hardness of the St. Demetrios ore in comparison to that from Viper, it will act as a grinding agent in addition to the balls in the SAG (semi-autogenous grinding) mill. Native gold will be recovered by a gravity method, using a Knelson Concentrator, and the sulphide minerals will be recovered as a concentrate using flotation cells. The initial rougher concentrate from the flotation circuit will pass through a cleaner circuit to produce a saleable gold-copper (sulphide) concentrate that will be exported directly to a commercial smelter. The tailings from these units, which will contain very few sulphides, can then be treated in a standard carbon-in-leach circuit where cyanide consumption is low and leach recoveries enhanced. Finally all the tailings will pass through a cyanide destruction system in order that they may then be disposed of without any safety worries. Some $60 \%$ of the tailings will be mixed with cement and pumped underground to fill the Viper stopes and prevent surface subsidence, with the remainder going to the specially constructed storage facility in Zestoremma Valley.

Up to $30 \%$ of the gold will be recovered from the Knelson and the cyanide leaching, this will be smelted on site to produce dort. Together with that recovered from the smelting of the exported concentrates; the overall gold recovery should not be less than $94 \%$.

\section{ENVIRONMENTAL PROTECTION}

The proposed mining development has been designed so that its environmental impact lies well within the acceptable limits not only during the life of the operation but after its closure. The Sappes Project presents an elegant solution to all of the main points on which mining is often criticised:

- Over $80 \%$ of the rock mined will be extracted from the Viper orebody, over $200 \mathrm{~m}$ below surface. With access by portal, the visual impact of the operation will be minimal.

- Approximately $60 \%$ of the tailings and almost all of the waste rock from the Viper mine will return underground to fill the stopes and to support the roof of the mine. No subsidence will occur at the surface above the mine.

- The flotation circuit has been designed such that non-recoverable base metal sulphide minerals will be segregated, mixed with cement and returned underground to fill the Viper stopes.

- The remainder of the tailings to be directed to the storage facility in Zestoremma Valley will contain almost no sulphide minerals and have a very low metal content. The addition of lime to this material will help bond the rock particles to form a safe and stable deposit, eliminating the possibility of acid drainage or base metal leakage from the storage facility.

- Residual free cyanide in the tailings will be detoxified using the world-renowned SO2/Air method designed by INCO. Testwork on Sappes samples by INCO has shown that the level of free cyanide in tailings waters after detoxification can be reduced to a level 50 times lower than the internationally accepted limits for tailings discharges.

- Sufficient sources of industrial-quality water have been located within the Project area, eliminating the need to use existing local supplies.

- On mine closure, access to all underground workings will be sealed and all traces of the operation removed. Similarly, the treatment plant will be dismantled and removed. These affected areas and also the stabilised tailings storage facility will be covered with topsoil and planted with vegetation similar to that covering the unaffected surrounding areas.

\section{FINANCIAL ASPECTS}

To-date, the Company has invested 6.5 billion drachmas in exploration programmes, metallurgical studies, environmental monitoring surveys and the preparation of reports. The capital cost for the mining project is estimated at US\$45 million, all of which will be financed through the Company.

The project will provide employment for up to 300 people during the two-year construction period and 126 will be directly employed in the operations once mining commences. According to international statistics, for every person directly employed in such a project, a further 2.5 to 3 jobs will be created with companies supplying services and local contractors. The Company is reviewing a number of additional offset benefits that may be offered to the local community. 


\section{REFERENCES}

BRIDGES, P. S., GORDON, M. J., MICHAEL, K \& ABATZIOGLOU, M. 1997. Gold mineralisation at Sappes, Northern Greece. "Europe's Major Gold Deposits", Irish Association for Economic Geology, 95-107.

DEWEY, J. F. \& SENGÖR, A. M. C. 1979. Aegean and surrounding regions: Complex multiplate and continuum tectonics in a convergent zone. Geol. Soc. Am. Bull. 90, 84-92.

INNOCENTI, F., KOLIOS, N., MANETTI, P., MAZZUOLLI, R., PECCERILLO, G., RITA, F. \& VILLARI, L. 1984. Evolution and Geodynamic significance of the Tertiary Orogenic Volcanism in N. E. Greece. Bull. Volcan. 47, 25-37.

MICHAEL, K. 1993. Geology and geochemistry of epithermal gold deposit in Konos area. Int. Report, I. G. M. E. Xanthi 75, $77 \mathrm{pp}$.

SKARPELIS, N. 1999. The Agios Filippos ore deposit, Kirki (Western Thrace). A base metal part of a high sulfidation epithermal system. Bull. Geol. Soc. Greece 33, 51-60.

VOUDOURIS, P. 1993. Mineralogical, geochemical and fluid inclusion studies on epithermal vein type goldsilver mineralisation at Kassiteres, Sappes (N. E. Greece). Unpublished PhD thesis, University of Hamburg, 218 pp. (In German). 